\title{
Rethinking field research: accounts and
} places

\author{
Peter Spink \\ Programa de Pósgraduação em Psicologia Social \\ Pontifícia Universidade Católica de São Paulo \\ Spink@fgvsp.br
}

The dominant narrative present in much of current psychological research and teaching is that which sees empirical science in general as a very special program of activity, having as its goal what Richard Rorty has called "Redemptive Truth". That is "..a set of beliefs which would end, once and for all, the process of reflection on what to do with ourselves" (2000 p2); a belief that there is "..something behind the appearance, the one true description of what is going on, the final secret"(2000 p.2), fulfilling the need that religion and philosophy have attempted to satisfy. Because they carry humanity's hopes for the future on their shoulders, scientists see themselves as special people, carefully trained and who go about their tasks in equally special ways. Care must be taken with measures, observations must be objective and correct procedures must be followed in order to avoid the observer contaminating the observed and to guarantee that results are fit for consideration.

Whilst the empirical science orientation is clearly strongest in experimental psychology or laboratory research, the hegemony that these areas exercise over the rest of the discipline is very great including over social psychology. Qualitative research approaches are required to show that those who carry out open interviews have been correctly trained, that the subject matter has been correctly registered and that proper methods of analysis used. Qualitative methods have to be "triangulated" in order to demonstrate the validity of conclusions. Those who advance beyond the laboratory or interview room and go into the 'field' are required to treat the 'field' in a similar manner. The 'field' is seen as a place where psychologists go to gather 'data' which they bring back for analyses. The growing use of terms such as 'ethnography' in social psychology is much more a consequence of this pressure than it is of a sudden interest in anthropology; after all, it is not very easy to give a scientific spin to activities like "hanging about in cafés", "walking aimlessly around streets", "overhearing conversations", "chatting to people in queues".

Key to this initial conception of "field" is the idea of difference, not just as a place but, following the transference of Malinowski's long conversation with the Trobriand Islands between 1914 and 1918 to Park's Chicago in 1925, as an analytic process in which the other is regarded as a stranger, or is "strangerized". We use terms like "distance", "separation" and, of course, "objectivity", lots of "objectivity". However, when ordinary people - and that includes psychologists when they are not being psychologists - meet other people for the first time they normally try to get to know them, to come closer to them. They seek in other words to de-strangerize the other, to bring people together.

Now the need for some kind of collective judgment about the validity of what is being discussed in social psychology or any other field of activity, academic or otherwise, is not, in itself, problematic. 
Disciplinary requirements of some kind will be found in any field of knowledge for as Fuller pointed out in his discussion of social epistemology (1991) disciplines are "bounded" by their procedures for adjudicating knowledge claims. On the more general level, Habermas's discussion of communicative action (1984) reached a similar position in discussing the requirement for truth, rightness and sincerity as ascribed intersubjectively by speakers and hearers to themselves. Rules, therefore, in and of themselves, are not the issue. In the same way, truth as an ordinary everyday notion that is used by people as part of their ongoing activities is also not an issue. It enables us to say things like " $2+2=$ 4", "when water boils at sea level it is hotter than when it boils on the top of a mountain", "it rained yesterday", "you get a better discussion when people can sit around a table" and "late modernity is permeated by risk discourse". The problem is with what happens when "rules" and "truths" as intersubjective conversational aids that we use to try and improve our collective life, find themselves subordinated to the despotical reign of methodological tyrants hiding behind a disciplinary state in the name of the great truth.

Perhaps one of the most important contributions of the post-constructionist perspective, is that which has argued that science - and social science especially - is really just another social activity in which meaning is negotiated and constructed. As such it is just one of the many everyday examples of a collective competence in everyday knowledge production carried out by communities and peoples. 'Telling it and talking about it' or to use the more academic terms 'narrating and conversing' are social givens, equally bound by the pragmatic ethics of communicative action.

To return to Rorty, "The problem about the attempt by philosophers to treat the empirical scientist as a paradigm of intellectual virtue is that the astrophysicists love of truth seems no different from that of the classical philologist or the archive oriented historian. All these people are trying to get something right. So, when it comes to that, are the master carpenter, the skilled accountant and the careful surgeon. The need to get it right is central to all these people's sense of who they are, of what makes their lives worthwhile"(2000, p.8). Practical problem-solving is something that psychologists, plumbers, cooks, small family farmers and communities and neighborhoods see themselves as competent at and in solving problems, existing knowledge is added to and changed. As George Herbert Mead put it " Knowledge, I conceive, is the discovery through the implication of things and events of some thing or things which unable us to carry on when a problem has held us up. It is the fact that we carry on that guarantees our knowledge" (Mead, 1956 p.322).

Head chefs start out by learning how to peel potatoes, skilled mechanics by cleaning equipment, research psychologists by typing out the contents of taped interviews and community leaders by helping with the neighborhood association files and writing up meeting notes. It takes time to become good at any-one of them. To make a soufflé, take a nuclear reactor apart, lead a major program of social investigation or represent the neighborhood in its confrontation with the municipal government.

Now this proximity with other disciplines, with chefs, plumbers and community activists, places our redemptive truth seeking methodological tyrant in a difficult situation. Whose knowledge is good knowledge, or useful knowledge or correct knowledge? Is common sense an inferior form of reasoning, made up of the left-overs from local and traditional knowledges, something that must be disciplined by sound scientific argument, or does it on the contrary serve to organize in any one specific local culture - even that of the individual professions - the different knowledges that are available? Is it procedure that produces knowledge or is it conversation? What would happen to method once "methodology" is reduced to the "methodical" and once "knowledges" began to become 
less vertical. What happens to the distance between the "participant observer" and the "stranger" once we accept that "distance" is not a particularly communal way of going about life.

In this paper I would like to look at just a few of these questions in relation to two linked and extremely problematic themes: firstly the dominant and largely inherited notion of "field" as a specific place where psychological relevant data can be gathered and, secondly, with the view that participatory actionresearch can in some way resolve social psychology's moral dilemma about knowledge and action. The result, I will seek to suggest, is that we need to forget about interpreting, analyzing, systematizing and believing that we can provide a better representation of reality and get on with telling others what people are telling us and suggesting different ways of thinking about questions and issues that may be more helpful than what we have to date. There is no great truth behind the suggestion by Amartya Sen (1999) that defining poverty solely in terms of income doesn't help to deal with the many other restrictions of gender, class, ethnicity and access to services including justice that are also involved; but it certainly moved the discussion forward in a big way.

\section{Redescribing the field}

The classical and still dominant view of the "field" amongst social psychologists is that which refers to a place where people can be seen in their "natural" habitat. It is a "field" that exists in a specific "place" and when the researcher is no longer in the specific "place" he is no longer in the "field". Being in the "field" can be either a lengthy living-in process of participant-observation or just a series of visits. On returning from the "field" the researcher will then examine the "data" that has been collected, discuss its theoretical importance and write up the conclusions for publication.

For Kurt Lewin (1952) the "field" was something else; it was an approach to the analysis of situations and settings that involves understanding the constellations of forces that are acting within the larger setting, both psychological and non-psychological. It was no longer a specific place but, rather, a web of effects, well described in his study of eating habits and in his expression "what is real is what has effects".

"Food habits do not occur in empty space. They are part and parcel of the daily rhythm of being awake and asleep; of being alone and in a group; of earning a living and playing; of being a member of a town, a family, a social class, a religious group, a nation; of living in a hot or a cold climate; in a rural area or a city, in a district with good groceries and restaurants or in an area of poor and irregular food supply. Somehow all of these factors affect food habits at any given time." (Lewin, 1952, p174).

Lewin's field approach - ignored by the reductionist, experimentalist and psychological social psychology of his time - provides us with a different perspective on the field, one that shows some points of connection with that of Pierre Bourdieu. It advances in suggesting that the field, as a theme, is composed of many different practices and relationships, objects and people, but it remains tied to the idea of the possibility of an independent description.

Now, if we turn for a moment to the Bahktinian suggestion of the dialogical character of any utterance, we will rapidly reach the conclusion that Lewin did not accidentally bump into food habits. On the contrary, he got himself into the question of food habits because he and others though it was something that psychologists could contribute too. Somebody talked to him or asked him a question. 
Redescribing "food habits", this time with Lewin present, enables us to think of the field as neither a separately existing space-place nor a separately existing constellation of forces, but as field, theme, or as I would prefer "theme-field", that we have declared social psychologically relevant and in doing so have re-located ourselves within it. For when Lewin got into food habits, he also became part of the "theme-field" of "food habits" which includes being prepared to argue that talking about "food habits", including the very idea of "food habits" is, form the position of a social psychologist, socially relevant. If Lewin was a nutritionist, or an anthropologist, a chef or a member of an anti McDonalds natural food pressure movement, he would also have placed himself in the field of "food habits", in the same way as a mother or father who reads the newspaper and brings the discussion about nutrition to the other members of the family sitting around the kitchen table.

Kingdon in the area of public policy developed the very useful term of the Agenda to describe how certain issues got themselves into the public action domain (1995). To some extent we are looking at a parallel process in terms of the field. The "field" does not pre-exist in some kind of botanical manner, it is argued into existence. lan Hacking provided an excellent example in discussing the idea of the "woman refugee".

"Ideas do not exist in a vacuum. They inhabit a social setting. Let us call that the matrix within which an idea, a concept or kind, is formed.[... The matrix in which the idea of the woman refugee is formed is a complex of institutions, advocates, newspaper articles, lawyers, court decisions, immigration proceedings. Not to mention the material infrastructure, barriers, passports, uniforms, counters at airports, detention centers, courthouses, holiday camps for refugee children. You may want to call these social because there meanings are what matters to us, but they are material, and in their sheer materiality make substantial differences to people. (1999,p.10)

All the events, the polyphony of multiple conversations, that are continuously forming and reforming the theme-field happen in places, in spaces and at times. Some can be more central than others, more accessible than others or more widely known that others. Some conversations happen in bus queues, others in the bakery, in university corridors, in bars and other are mediated by journals, magazines, newspapers, radio and television. Others are present in artifacts and objects, parts of previous conversations that happened a long time ago. The social, to use the arguments of the actornetwork theorists is neither independent nor dependent on materials; on the contrary, materiality and sociality are two sides of the same coin (Law and Mol 1995).

Some theme-fields (that is the social idea of the importance of a concern and the argument of the usefulness of the term as a way of gathering together and linking different issues) have been declared social psychologically relevant so many times that we run the risk of assuming them as obvious, objectified as independent and autonomous facts - forgetting that as ideas, they did not grow up in a vacuum. For example: it was not very long ago that urban children owned the streets, nowadays "street children" are a problem. People who had deficiencies are now "challenged", poverty is something against which war is declared or is a disease to be "eradicated". "Communities" now need to be developed or are seen as "lacking" (carente).

When people who define themselves as researchers meet - be they psychologists, sociologists, biologists, historians or whatever - they usually ask each other "what are you working on". (By the way, carpenters and builders and surgeons also do that). When somebody replies, "I am working on the different ways in which the various international and national declarations about children and adolescents talk about children and adolescents", they are arguing firstly that this is an issue and, 
secondly or simultaneously, positioning themselves in it. Very much in the same way that somebody may have asked Lewin a similar question - "Hey Kurt, what's new?"- and received the answer - "food habits".

What I want to suggest is that when we reply to this question we are saying, for all extents and purposes that we are "in the field". We are not in the field because we went off to the Torres Straits, the Trobriand Islands, or to the North Side of Chicago; we are in the field because we are "in" the theme-field as issue and argument, as action and account - to return to the ideas of Harold Garfinkel (1967). It doesn't matter whether we are doing ordinary research with a grant, action-research, community work, taking part in advisory committees, working with advocatory organizations, writing books, giving talks, conversing, or looking through our notes - we have placed ourselves in the themefield.

Now if there is no fundamental difference between curiosity and science, then investigating or researching is really just another way of "talking the world". Social research is just as much a social product of talking the world, as it is a producer of talk. In "talking the world", the members of any discipline, whether it be local knowledge, common sense (Geertz 1983), custom and practice (Thompson 1993) or the various disciplines that we call academic, will act on the basis of a shared collective faith that they are doing so in the common interest - that they are a legitimate part of the commons and producing public goods. That is, that they are moving things onwards.

Thus, given that the day-to-day of social psychological investigation shares a common boundary with social curiosity, we should be as prepared as any other to reply in an ordinary manner to such ordinary questions as: What does it have to do with you? What have you got to contribute? Why do you think it is important? How can you help? To answer that we are doing research, or that we are scientists, or that we are advancing human understanding, is to deny dialogue and to verticalize knowledges; it is to appeal to the despotic power of the great truth.

Becoming part of a theme-field is not an occasional weekend of participant observation in some exotic place but is, on the contrary, the ethical and political conviction that as social psychologists we are in the theme-field because we think that the words that make up the idea are useful, that they redescribe questions in a way that is collectively helpful and that we think that as social psychologists we can make a contribution. Making a contribution, we hasten to add, is something very different from assuming proprietary ownership of an issue or of the techniques of its resolution; something unfortunately that the "psi" professions have only too readily been interested in assuming (Rose, 1998).

\section{Redescribing knowledge and action}

Being active members in a theme-field creates a series of difficulties for the ways in which social psychologists have sought to resolve the moral dilemmas surrounding knowledge and action. For example, asking people to sign an "informed consent" declaration or having your "research" approved by the university "ethical committee" does not seem a very helpful way of resolving our engagement in a specific issue. 
In general, social psychologists have adopted one or other of two basic approaches: firstly, the dissemination of correctly derived knowledge and, secondly, the various versions of action research, participant action research and participative research.

The first of these tends to argue that if we do our job correctly as disciplined scientists then we will produce good ideas and suggestions for action and that these will drift across the gap between knowledge and action and become a useful practice. The assumption is that the path from knowledge to action is a smooth and democratic process, in which intrinsically good ideas are automatically adopted. The belief is that knowledge spreads outwards like the circles on the water after the stone is thrown. It is a belief that sustains, journals, research grants, distinctions between pure and applied research. However it does not hold up very well to inspection as people like Bruno Latour (1987) have shown when taking a closer look at how ideas move around, or when we ask our so-called applied colleagues about the ideas they use in their practice .

The second approach, involving various versions of action research, was, and still is, social psychology's main alternative attempt to break through the dilemma of research and practice. However it remained an attempt; action-researchers are still looked on as outsiders, as activists masquerading as scientists or as good hearted but methodologically insane. In the beginning, the action-research approach tended to focus the idea of raising social awareness through research and building a bridge between researcher and non-researcher; but over time it developed into a much more balanced approach to mutual learning and agenda-sharing. Along the way many new forms of relationship between researchers and communities were created (Sommer, 1990).

Action research, especially in its various participative versions was to be very influential in community psychology and, for a number of us who shared its principles (Spink 1977) showed possibilities. But it too is driven by the notion that research and action, even though they may be closely linked, are separate. Even the most participative oriented action-researcher or community based psychologist will still hold on to the notion that there is something called research and that research is somehow special. Peter Reason and Hilary Bradbury in their Handbook of Action Research: participative inquiry and practice will say:

"A primary purpose of action-research is to produce practical knowledge that is useful to people in the everyday conduct of their lives. A wider purpose of action research is to contribute through this practical knowledge to the increasing well-being -economic, political, psychological, spiritual - of human persons and communities..... (2001 p.2)"

The idea is clear, the meta-narrative is present and it is one that is shared by most committed actionresearchers. Action-research generates knowledge and science is somehow special, it can provide people with new ideas. Even if we do this in a democratic and openly participative way, it still is special for it creates knowledge. We would not say the same about traditional knowledge, local knowledge or common sense. The very idea of a "primary purpose" and a "wider purpose" already suggests that we are different. This implies that we as researchers or scientists know things that others don't and that we can "choose" to use this in an open or a closed manner. But note that we are saying that the choice is ours. We can choose to be "researchers" or we can choose to be "action-researchers".

Yet common sense is also equally a knowledge generating process, routing its users around a locally situated commons, just in the same way that Google routes us around the internet commons (Geertz, 1983, Lessig 2002). It can be found in the question: "does that make sense?", or, "What would you do if you were me?" All of us assume that there are traditional and practical knowledges that can be 
drawn on in a variety of circumstances, just as we assume that there are knowledges produced by scientists and engineers and plumbers that are also useful. It is just as much common sense to assume that in a culture where men look after children, men will know a lot about children, or that in a society where children look after water buffalo they will know a lot about water buffalo as it is to ask the pharmacist about a medicine. People don't need to produce practical knowledge - it comes in the process of living.

If knowledge is the Achilles tendon on the left foot of action-research, methods occupy the same place on the right foot. Action-researchers have had to pay the price of psychology's grudging acceptance of their peripheral existence through loyalty to "methods". The other day I heard a community researcher talking about the importance of circular meetings and I wondered what that was. Could it be meetings that went on and on, with arguments going round and round in circles? We have lots of those in the university. No, it meant that the researcher sat everybody around in a circle so that they could see each other. Doing what for most of us in everyday life is common sense, becomes part of the "method". Now obviously this is a specific event, but think how what we used to call group discussions became focus groups and how many other ordinary accessible activities carried out by ordinary people in the world became subtly or not so subtly transformed by the importance of the "method".

In conversation with Peter Reason (Reason 2003), Rorty was to say about the more progressive versions of action research : "..when you define action research... you might as well be describing democratic politics, it doesn't bear particularly on social science, it is just what people in democratic societies hope to be doing...".(p. 109).

Is there life beyond the meta-discourse of science, beyond the clinging grasp of its materialist metaphysics? Can we just assume that we are here like plumbers, cooks, firemen, herbalists, community leaders and others to try and build utopias? Can we make the move from research carried out with a vague hope of action, to action understood as a practise that requires knowledge and problem solving? Can we forget about methodology and recover the ethics of the methodical, understood as the relatable and the accountable? Can we accept that to be rigorous is to be open for inspection, to be visible and communicably coherent and is not guaranteed by an obscure reference to this or that method or textbook? Can we accept and recognize that methods create realities? That multiple approaches to being with others are important because they create chatter and interconnection, argument and debate; not because they guarantee objectivity through triangulation? Can we get away from translating, systematizing and producing knowledge and get into re-arranging, calling attention and pushing ideas around; re-describing rather than interpreting? Can we learn how to talk in and from the field and not "about the field", reabsorbing research as a taken-for-granted part of being social psychologists, of being in "action"? Can we re-learn how to be useful, to solve problems, picking up the bits and pieces, the stories, listening to the places where they come from and trying to re-tell these in ways that help to move things on? Can we learn to do this in ways that are available in the day to day to any normally active and competent member of a social community and are, therefore, communicable and debatable? Are we prepared to write in ways that people can relate to, instead of writing in ways that say "we are special"? Are we prepared to give up the search for the ultimate answer, the great truth, to accept the de-verticalization of knowledge and get on with just being good social psychologists trying to solve problems, positioning ourselves in theme-fields and getting angry about issues like inequality, poverty, corruption and rights? Just in the same way as good plumbers, engineers, taxi drivers, cooks and small family farmers get angry about other issues and in doing so help to build utopias. 
Backing away from redemptive truth does not mean backing away from training, from discussing what to do and how, but it does mean positioning these discussions in a different way. A way that brings together the best of the two traditions - research and action-research - and redescribes them as action, as what social psychologists do; just like carpenters, surgeons, dentists, activists and everybody else who is trying to make a difference.

\section{References}

FULLER, Steve. Social epistemology. Indiana Univesity Press, 1991.

GARFINKEL, Harold. Studies in ethnomethodology. Englewood Cliffs, Prentice Hall, 1967

GEERTZ, Clifford Local Knowledge. New York: Basic Books, 1983

HABERMAS, Jurgen. The theory of communicative action. Vols. 1, 2, Beacon Press, Boston, 1984.

HACKING, lan. The social construction of what. Cambridge,Mass: Harvard University Press, 1999

KINGDON, John W. Agendas, Alternatives and Public Policies. Addison Wesley, 1995

LATOUR, Bruno. Science in Action. Cambridge, Mass: Harvard University Press, 1987

LAW, J. \& MOL., A. Notes on Materiality and Sociality. The Sociological Review. 43, 2, 274-294, May, 1995

LESSIG, Lawrence. The future of ideas: the fate of the commons in a connected world. New Yor: Vintage Books 2002

LEWIN,Kurt. Field Theory in Social Science - selected theoretical papers by Kurt Lewin. ( Ed. CARTWRIGHT,D) London: Tavistock Publications, 1952

MEAD, Geroge $\mathrm{H}$. in STRAUSS, Anselm. (ed) The social psychology of George Herbert Mead. University of Chicago Press, 1956.

REASON, Peter. Pragmatist philosophy and action research. Action Research, 1,1, 103-123. 2003

REASON Peter and BRADBURY, Hilary (eds). Handbook of action research: participative inquiry and practice. London: Sage Publications 2001

RORTY, Richard. The Decline of Redemptive Truth and the Rise of a Literary Culture. November 2, 2000. http://www.stanford.edu/ rrorty/decline.htm (16th november 2005)

ROSE, Nikolas. Inventing our selves. Psychology,Power and Personhood. Cambridge: Cambridge University Press, 1998

SEN, Amartya. Development as Freedom. Oxford: Oxford University Press, 1999

SOMMER, Robert. Local Research. Journal of Social Issues. 46, 1, 203-214, 1990

SPINK, Peter. Action Research and Complex Social issues Annual Conference of the Sociedade Brasileira para o Progresso da Ciência, Brasília. Tavistock Institute,doc. 2T, 91, 1977. 
Pesquisa Ação e a Análise de Problemas Sociais e Organizacionais Complexos, Psicologia (USP), 5, 1, 1979

THOMPSON, Edward.P. Customs in Common New York, The New Press, 1993

\section{Formato de citación}

Spink, Peter (2005). Rethinking field research: accounts and places. Athenea Digital, 8, x-x. Disponible en http://antalya.uab.es/athenea/num8/Sspink en.pdf

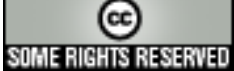

Este texto está protegido por una licencia Creative Commons.

Usted es libre de copiar, distribuir y comunicar públicamente la obra bajo las siguientes condiciones:

Reconocimiento: Debe reconocer y citar al autor original.

No comercial. No puede utilizar esta obra para fines comerciales.

Sin obras derivadas. No se puede alterar, transformar, o generar una obra derivada a partir de esta obra.

\section{$\underline{\text { Resumen de licencia }}$}

\section{$\underline{\text { Texto completo de la licencia }}$}

